\title{
Social Determinants of Health and Health Equity among the Elderly People in Mountain Region of Uttarakhand
}

\author{
Dr. Hari S. Bisht \\ Senior Fellow, ICSSR, School of Social Sciences, Uttarakhand Open University, Haldwani 263139, Nainital, Uttarakhand, \\ INDIA
}

\begin{abstract}
According to World Health Organization (WHO), the Social Determinants of Health (SDH) have an important influence on health inequities - the unfair and avoidable differences in health status seen within and between countries. In countries at all levels of income, health and illness follow a social gradient: the lower the socioeconomic position, the worse the health. The main objective of this paper is to understand these determinants that are prevailing and its relation with the health status of the elderly people in mountain region of Uttarakhand. In order to accomplish the study the data have been collected from 183 households from the three different geographic mountain areas of six administrative regions. The collected data have been further analyzed with SPSS latest version. The findings of study shows that $\&$ the self stated very poor health status majority were from the Garhwal mountain region, females those were widows, those were above 81 years, Shudra by caste followed by Khatriya caste, residing in joint family, living in Kuchha houses, civil pensioners, educated above high school \& above and average income group followed by high and low income group of the elderly households. However, with respect to the poor health status, occupation, education and income of the household of elderly as the p-values associated with the Ch-square statistics are found to be less than the level of significance. The study concluded with that in built environment of the elderly people like the region, caste, being a female and widow and age above 81 years followed by living amenities like Kuchha house and residing in a joint family system are more significant with respect to the poor health status, while occupation, education and income of the household of elderly as the p-values associated with the $\mathrm{Ch}$-square statistics is found to be less than the level of significance in the mountain region of Uttarakhand.
\end{abstract}

KEYWORDS: Elderly People, Health Equity, Mountain Region, Social Determinants of Health (SDH), Uttarakhand

\section{INTRODUCTION}

In 1948, the establishment of the World Health Organization embodied a new global vision, emerging from the ashes of conflict, of universal health at the highest attainable level. Thirty years later, in 1978, the community of nations came together again in Alma-Ata to call for a new approach to health, one founded in a holistic understanding of local primary health-care needs, across the social determinants, and of people-centered action.[1]

The primary health-care movement, though sometimes overshadowed by disease-specific concerns, never died. Indeed primary health care, once again, plays a central role in WHO's current agenda. The 1986 Ottawa Charter on Health Promotion, [2] and its renewal in Bangkok, embraced a truly global vision of public health action and the importance of social determinants of health approach. [3]

According to WHO defination "Social determinants of health (SDH) are the conditions, in which people are born, grow, work, live and age and the wider set of forces and systems shaping the condition of daily life."(4) At the heart of the concern with social determinants of health, and health inequity, is concern for people without the freedom to lead flourishing lives. [5]

A social determinant of health approach has several advantages. It bridges the artificial distinction between technical and social interventions, and demonstrates how both are necessary aspects of action. It seeks to redress the imbalance between curative and preventive action and individualized and population-based interventions. Also, by acting on structural conditions in society, the social determinants approach offers a better hope for sustainable and equitable outcomes. [6]. It is now recognized that an increase in national income, by itself, does not capture development in its fullest sense. At least, education and health should be included. [7] 


\section{International Journal of Current Science Research and Review}

ISSN: 2581-8341

Volume 04 Issue 10 October 2021

DOI: 10.47191/ijcsrr/V4-i10-19, Impact Factor: 5.825

IJCSRR@ 2021

WwW.ijcsrr.org

In 2008, the Commission on Social Determinants of Health (CSDH) recommended that WHO support health-equity impact assessments of important global, regional, and bilateral economic agreements and in all government policies, including finance, as a way to address health disparities. It was recommended that member states of WHO redesign their health sectors to integrate a focus on social determinants of health into relevant sectors. [5]

To achieve that goal, WHO proposed that countries adopt and perform Health Impact Assessments (HIAs) for policies and projects and focus further on health equity. The Commission for Social Determinants of Health (CSDH) also recommended that data systems present information disaggregated by sex, socio-economic status, and other criteria to allow for the identification of disparities; it warned that public participation does not necessarily ensure that equity issues are addressed; and it called for capacity-building to assess the health-equity impacts of major global, regional, and bilateral economic agreements and to monitor social determinants of health and health equity.(CDHS,2008).

\section{OBJECTIVES}

a. To find out the social determinants of health towards health equity \& healthcare access among the elderly people in the mountain region of Uttarakhand;

b. To evaluate the health status and its relation with social determinants of health among the elderly people of the region.

\section{METHODOLOGY \&STATISTICAL ANALYSIS}

As the study aims to find out the Social Determinants of Health (SDH) among the Elderly People of Mountain Region in Uttarakhand, the study is interdisciplinary in its nature and scope. Hence, a cross-sectional descriptive and diagnostic research design has been applied. A multy-stage sampling plan has been utilized to gather the primary data.

The study households have been sampled in a total of numbers of 183 (approximate 30 households per village) only visited due to limitations of COVID-19. These sample households were selected from an average of representing to Uttarakhand both mountain regions in Garhwal and Kumaun Mountain Regions, of all altitudes (i.e.), Greater Himalaya, (Villages from Chamoli Garhwal \& Pithoragarh Districts) Trans Himalaya,(Villages from Almora \& Pauri Garhwal Districts) and from Vallies (Villages from Bageshwar \& Rudraprayag Districts), from both the administrative divisions, districts, blocks, and health facilities along with representation of urban/rural.

\subsection{Tools for Data Collection}

An interview schedule was developed for the primary data collection according to the study objectives and the same has been applied among ten elderly household before utilizing it to the study areas. The interview schedule has both open ended and closed ended questions developed in English and used in Hindi and local dialects (i.e. Garhwali \& Kumouni) as well. Interview Schedules for a Community Leader of study village, Medical Officer of local health facility for getting key Information as also developed and utilized getting key information of village and elderly health. Due to hilly terrains of the mountains the study areas visited in three phase. In first phase Almora, and Pithoragarh of Kumaun mountain region were visited and named it SDC-1, during second visit Chamoli and Rudraprayag are being covered and in SDC-3 phase Pauri Garhwal covered to gather the primary data.

\subsection{The Stastical Analysis}

The collected data were further analyzed by using SPSS package of latest version of computer software. After generating Tables based on different variables, Ch-squire Test was applied.

The descriptive analysis was performed for the establishing the association in between the variables, with the support of crosstabulation. Finally, the major findings have been presented for making the relevant interpretation and conclusion in persuasion of study objectives.

\section{FINDINGS}

\subsection{Demographic Profile of the Elderly People}

Out of the total 183 sampled households elderly 91 (47.7 per cent) belongs to Kumaun mountain region, while 92 (50.3 per cent) to Garhwal mountain region of the state. On village/development block/district wise calculation in each sampled village situated 


\section{International Journal of Current Science Research and Review}

ISSN: 2581-8341

Volume 04 Issue 10 October 2021

DOI: 10.47191/ijcsrr/V4-i10-19, Impact Factor: 5.825

IJCSRR@ 2021

WWw.ijesrr.org

in the three districts, there were 30 (16.4 per cent) household of elderly each belongs to Erha Village of Dwarahat development block in Almora, Kapkot Village of Kapkot development block in Bageshwar and Gair Village of Gairsain block in Chamoli Garhwal. While, each 31(16.9 percent) belongs to Kasana Village of Nainidanda development block, Pauri Garhwal, Gewala village of Augustmuni development block, Rudraprayag \& Nagila village of Berinag development block in Pithoragarh districts respectively.

By sex of the household elderly in the study villages 101(55.2 per cent) were male and 82(45.8 per cent) were female respondents. Out of them 92(50.2 per cent) elderly were married followed by 90 (49.2 per cent) widowers/widows and only 1 ( 0.5 per cent) elderly were unmarried. By caste majority elderly households belongs to Khatriyas caste 93(50.8 per cent) followed by Shudras caste 54 (29.5), Brahamins 30 (16.4 per cent) and Vaishya 6(3.3 per cent).Constitutionally, the categories of the elderly households were; 133 (72.7 per cent) General, 46(25.1 per cent) to Scheduled Caste (SC) \& Scheduled Tribes (ST), while remaining 3(1.6 per cent) belongs to Other Backward Classes (OBC) and finally 1(0.5 per cent) elderly was missing and stated no category. A majority 174 (95.1 per cent) of elderly are living in a joint family, while a remaining few 9(4.9 per cent) lives in a nuclear family. By family size majority 96 (52.5 per cent) of elderly people are living a three to four members family followed by 58 (31.7 per cent) in one to two members and 29 (15.8 per cent) currently living a five or more members size family in the study villages. A few 13 (7.1 per cent) elderly household were migrated from other places, while a majority 145 (79.2 per cent) were natural inhabitant of their current village and a significant numbers 25(13 .7 per cent) elderly did not know about their migrant history.

Majority 76(41.5 per cent) elderly people were among them under the age group of 60 to 69 years, followed by 73 (39.9 per cent) under the age group of 70 to 79 years,26(14.2) per cent under the age group of 80 to 89 years, While a few 4 (2.2 per cent) followed by 3(1.6 per cent) and also 1(0.5 per cent) elderly were household head under the age group of 50 to 59 years, 90 to 99 years and above 100 years respectively.

\subsection{Socio-Economic Profile of Elderly People}

More than a quarter 28.4 per cent of elderly people were dependent on Social Pension Schemes of the Government followed by Pensioners of Army or Para-Military Forces (22.4 per cent), Pensioners of Civil departments or semi-governments or private services (19.1 per cent), while a significant number 29 (15.8 per cent) belongs to laborers or dependent on family and remaining 14.2 per cent were dependent of agriculture or artisanship among the study villages.

Educationally, a majority 45.4 per cent elderly people were illiterate followed by 15.3 per cent has taken formal to primary education, up to high school 12.0 per cent, middle (up to class $8^{\text {th }}$ ) 10.4 per cent , intermediate 7.1 per cent, while 5.5 per cent were post graduate and 4.4 per cent elderly people were educated up to graduate level.

By income of the elderly house hold a majority 81 (44.3 per cent) were dependent a mere income of rupees 2000 or less, while 36 (19.7 per cent) elderly people were in between the income bracket of rupees above 2000 and below 10,000, followed by 37 (20.2 per cent) in between above rupees 10,000 and below 20,000, 24 (13.1 per cent) in between above 20,000 and below 30,000 and only 5(2.7 per cent)elderly household belongs to an income of rupees 30,000 and above.

\subsection{Amenities of the Elderly Households}

It is a positive sign of development that among the all elderly household electricity were available as a majority $155(84.7$ per cent) households has a Uttarakhand Power Corporation (UPCL) electricity connection followed by 23(12.6 per cent) household got a power connection under Pradhan Mantri Gram Jyoti Yojna (PMGJY), while a few 5(2.7 per cent) households has Solar Power connection also. Potable water is a basic amenity for everyone 72(39.3 per cent) households for common distribution respectively in the study villages in mountain region. However, a significant number $28(15$. per cent) households still goes to local Dhara/Noula to collect the potable water, while a few 5 (2.7 per cent) households used both common piped water as well as visits to collect water from Dhara/Noula. A majority of households 178 ( 94.5 per cent) has toilet facilities in its premises , while a few 5( 2.7 per cent) have not the same. However, a few 5 (2.7 per cent) elderly after having the toilets facility in their household premises, did not use not the available toilets facility and goes for an open defecation.

By type of house a majority 141(77.1 per cent) households has a pukka house remaining 42(22.9 per cent) households' lives in kuchha houses in the study villages. A majority 177 (96.7 per cent) of households has LPG connection, out of them 28 (15.3 per 


\section{International Journal of Current Science Research and Review}

ISSN: 2581-8341

Volume 04 Issue 10 October 2021

DOI: 10.47191/ijesrr/V4-i10-19, Impact Factor: 5.825

IJCSRR@ 2021

www.ijesrr.org

cent) households has provided LPG connections through Pradhan Mantri Ujjwala Yojna (PMUY), while remaining a few 6 ( 3.3 per cent) households still uses Chulha as a mode of cooking.

Majority 165(90.2 per cent) households have a mobile phone, more than half 96 (52.5 per cent ) of them using smart phones, while a majority 147(80.3 per cent) households having TV/LED/Smart TV and a few 11(6.0 per cent) households have a Washing Machine.

\section{4: Land Ownership and Food Preferences}

The more than half 51.4 per cent elderly households owned stair type un-irrigated land and have marginal land while 46.4 per cent households have partially irrigated land in mostly plain areas in mountain region. Majority 71 per cent households still utilize local fodder in their small piece of land ownership. Out of total households Only 6 per cent household are commercially using their land.

Out of total surveyed households more than a half 58.4 percent has livestock ownership. A majority of them 38.3 has Cows only,5.5 per cent each households has buffalos or both Cows \& Buffalos both, while 3.8 per cent has Cows, Buffalos, Oxen \& Goats and a 2.7 per cent households each has Goats only and Cows, Buffalos and Oxen.

Majority 62.3 per cent household have both vegetarian and non-vegetarian preferences, while more than a quarter 29.5 per cent household have strictly vegetarian food preferences. Majority 73.2 per cent of households uses the milk for family use. Rice (94.5 per cent), Wheat (89.6 per cent) followed by Bajra (34.4 per cent), Jwar (32.2 per cent), as a major food stuff with Maize (39.9), Barley (27.3) Ragi (25.7 per cent) and a few Cereals (9.8 per cent) and supported food are utilized by the households in the study area. With reference to local pulses, majority 77.6 use Gahat, which has a medicinal value followed by Bhatt(72.7 per cent) while Masoor(65.0 per cent) \& Urad (63.4 per cent), Soya(38.3 per cent), Mung (35.5 per cent) gram(30.6 per cent) \& Bean (20.2 per cent) respectively. With respect to oilseeds majority 95.1 per cent of elderly households uses mustard oil followed by 37.7 per cent used soya been oil or both.

\section{5: Healthcare Access of the Elderly}

Table: 4.1 Healthcare accesses of elderly people in mountain region

\begin{tabular}{|l|l|l|}
\hline Treatment Taken & Frequency & Percent \\
\hline Allopathy & 117 & 75.9 \\
\hline Ayurvedic & 16 & 10.4 \\
\hline Spiritual/Faith Healer & 9 & 5.9 \\
\hline Homeopathy & 6 & 3.9 \\
\hline Other & 6 & 3.9 \\
\hline Total & $\mathbf{1 5 4}$ & $\mathbf{1 0 0 . 0}$ \\
\hline
\end{tabular}

The Table above indicates that the health care access of elderly people, those were sick or previously sick (Total 154) has taken treatment at the time of their need. It reflects that majority 75.9 per cent of elderly approaches to Allopathic treatment to cure their ailment. Further, a 10.4 per cent per cent elderly people has approached to Ayurvedic system of medicine followed by a 5.9 per cent spiritual, while 3.9 per cent people each access the Homeopathy\& other pathies respectively.

\subsection{Social Determinants of Health \& Health Status of Elderly People}

Table 4.2: Association between selected socio-economic \& demographic determinants and self stated health status of elderly people in mountain region.

\begin{tabular}{|c|c|c|c|c|c|c|c|}
\hline \multirow{2}{*}{$\begin{array}{l}\text { Socio-economic } \\
\text { \&demographic } \\
\text { Variables }\end{array}$} & \multirow[b]{2}{*}{ Categories } & \multicolumn{4}{|c|}{ Health Status } & \multirow[b]{2}{*}{$\begin{array}{l}\text { Totals } \\
(\%)\end{array}$} & \multirow{2}{*}{$\begin{array}{l}\text { Chi- } \\
\text { Square } \\
\text { (p- } \\
\text { Value) }\end{array}$} \\
\hline & & Very Good & Good & Fair & $\begin{array}{l}\text { Very } \\
\text { Poor }\end{array}$ & & \\
\hline \multirow[t]{2}{*}{ Region } & Kumaun & $18(19.8)$ & $34(37.4)$ & $26(28.6)$ & $13(14.3)$ & 91 & \multirow[t]{2}{*}{$\begin{array}{l}10.788 \\
(0.013)^{*}\end{array}$} \\
\hline & Garhwal & $33(35.9)$ & $18(19.6)$ & $22(23.9)$ & $19(20.7)$ & 92 & \\
\hline
\end{tabular}


International Journal of Current Science Research and Review

ISSN: 2581-8341

Volume 04 Issue 10 October 2021

DOI: 10.47191/ijcsrr/V4-i10-19, Impact Factor: 5.825

IJCSRR@ 2021

www.ijcsrr.org

\begin{tabular}{|c|c|c|c|c|c|c|c|}
\hline \multirow{2}{*}{ Sex } & Male & $51(50.5)$ & $42(41.6)$ & $6(5.9)$ & $2(2.0)$ & 101 & \multirow{2}{*}{$\begin{array}{l}129.332 \\
(0.000)\end{array}$} \\
\hline & Female & $3(3.6)$ & $10(12.2)$ & $39(47.6)$ & $30(36.6)$ & 82 & \\
\hline \multirow{3}{*}{ Age Group } & Below 70 Years & $18(22.5)$ & $34(42.5)$ & $26(32.5)$ & $2(2.5)$ & 80 & \multirow{3}{*}{$\begin{array}{l}84.026 \\
(0.000) \dagger\end{array}$} \\
\hline & 70 - 80 Years & $33(45.2)$ & $18(24.7)$ & $11(15.1)$ & $11(15.1)$ & 73 & \\
\hline & 81 Years and Above & $0(0.0)$ & $0(0.0)$ & $11(36.7)$ & $19(63.3)$ & 30 & \\
\hline \multirow[t]{2}{*}{ Marital Status } & Married & $51(55.4)$ & $41(44.6)$ & $0(0.0)$ & $0(0.0)$ & 92 & \multirow[t]{2}{*}{$\begin{array}{l}148.307 \\
(0.000) \dagger\end{array}$} \\
\hline & Widow/Widower & $0(0.0)$ & $11(12.1)$ & $48(52.7)$ & $32(35.2)$ & 91 & \\
\hline \multirow{4}{*}{ Caste } & Brahmin & $30(100.0)$ & 0 & 0 & 0 & 30 & \multirow{4}{*}{$\begin{array}{l}146.734 \\
(0.000) \dagger\end{array}$} \\
\hline & Kshatriya & $21(22.6)$ & $40(43.0)$ & $22(23.7)$ & $10(10.8)$ & 93 & \\
\hline & Shudra & $0(0.0)$ & $12(22.2)$ & $26(48.1)$ & $16(29.6)$ & 54 & \\
\hline & Vaishya & 0 & 0 & 0 & $6(100.0)$ & 6 & \\
\hline \multirow{2}{*}{ Type of Family } & Nuclear & $9(100.0)$ & $0(0.0)$ & $0(0.0)$ & $0(0.0)$ & 9 & \multirow{2}{*}{$\begin{array}{l}24.499 \\
(0.000) \dagger\end{array}$} \\
\hline & Joint & $42(24.1)$ & $52(29.9)$ & $48(27.6)$ & $32(18.4)$ & 174 & \\
\hline \multirow{2}{*}{ House Type } & Puckka/Modern & $38(26.9)$ & $46(32.6)$ & $35(24.8)$ & $22(15.7)$ & 141 & \multirow{2}{*}{$\begin{array}{l}5.726 \\
(0.126)\end{array}$} \\
\hline & Kuccha & $13(30.9)$ & $6(14.4)$ & $13(30.9)$ & $10(23.8)$ & 42 & \\
\hline \multirow{5}{*}{ Occupation } & Agriculturists & $26(100.0)$ & $0(0.0)$ & $0(0.0)$ & $0(0)$. & 26 & \multirow{5}{*}{$\begin{array}{l}388.391 \\
(0.000) \dagger\end{array}$} \\
\hline & Dependents & $25(48.1)$ & $27(51.9)$ & $0(0.0)$ & $0(0.0)$ & 52 & \\
\hline & Army Pensioners & $0(0.0)$ & $0(0.0)$ & $40(97.6)$ & $1(2.4)$ & 41 & \\
\hline & Civil Pensioners & $0(0.0)$ & $0(0.0)$ & $4(11.4)$ & $31(88.6)$ & 35 & \\
\hline & Others & $0(0.0)$ & $25(86.2)$ & $4(13.8)$ & $0(0.0)$ & 29 & \\
\hline \multirow{3}{*}{ Education } & Illiterates & $51(61.4)$ & $32(38.6)$ & $0(0.0)$ & $0(0.0)$ & 83 & \multirow{3}{*}{$\begin{array}{l}266.564 \\
(0.000) \dagger\end{array}$} \\
\hline & Up to High School & $0(0.0)$ & $20(29.0)$ & $46(66.7)$ & $3(4.3)$ & 69 & \\
\hline & Above High School & $0(0.0)$ & $0(0.0)$ & $2(6.5)$ & $29(93.5)$ & 31 & \\
\hline \multirow{3}{*}{ Income } & Low & $38(32.5)$ & $40(34.2)$ & $29(24.8)$ & $10(8.5)$ & 117 & \multirow{3}{*}{$\begin{array}{l}21.869 \\
(0.001) \dagger\end{array}$} \\
\hline & Average & $7(18.9)$ & $8(21.6)$ & $10(27.1)$ & $12(32.4)$ & 37 & \\
\hline & High & $6(20.7)$ & $4(13.8)$ & $9(31.1)$ & $10(34.4)$ & 29 & \\
\hline \multicolumn{2}{|l|}{ Total } & 51 & 52 & 48 & 32 & 183 & \\
\hline
\end{tabular}

* Significant association at 0.05 levels. $\uparrow$ Significant association at 0.01 levels. 


\section{International Journal of Current Science Research and Review}

ISSN: 2581-8341

Volume 04 Issue 10 October 2021

DOI: 10.47191/ijcsrr/V4-i10-19, Impact Factor: 5.825

IJCSRR@ 2021

WWw.ijesrr.org

The Table above depicts that the self stated health status of the more than one third 35.9 per cent of the respondents were very good in mountain region of Garhwal and below of one fifth 19.8 per cent in mountain region Kumaun respectively. $28.6 \%$ of respondents have fair health and $14.3 \%$ have very poor health status, while in the mountain regions of Garhwal, $35.9 \%$ of respondents have very good health, $19.6 \%$ have good health, $23.9 \%$ have fair health and about $20.7 \%$ of respondents have very poor health status. The result indicates that the Garhwal region has higher respondents in very poor health conditions. The association between region and health status of the respondents is found to be significant since the chi-square value is 10.788 with a p-value less than the level of significance (0.05). Hence it can be inferred that there is an association between health status and region.

The self stated health status of male respondents is: $50.5 \%$ very good, $41.6 \%$ good, $5.9 \%$ fair and $2.0 \%$ very poor respectively while the health status of females is respectively: $3.6 \%$ very good, $12.2 \%$ good, $47.6 \%$ fair and $36.6 \%$ very poor. Majority of the females have very poor health status. The association between sex and health status of the respondents is found to be highly significant since the chi-square value is 128.322 with a p-value less than the level of significance (0.05). Hence it can be inferred that there is a strong association between health status and sex of the respondents.

It can be noticed from the Table that majority of the respondents $(65 \%)$ with age below 70 years have good health status while $32.5 \%$ have fair health and only $2.5 \%$ have very poor health status. Majority of the respondents $(69.9 \%)$ in age group $70-80$ years have good health status, $15.1 \%$ have fair health and $15.1 \%$ have poor health in this age group. On the other hand, respondents who are 81 years and older, majority of them, have fair and very poor health conditions $(36.7 \%$ fair; $63.3 \%$ very poor). The results indicate that the older respondents have major health issues. In addition, the association between health status and age of the respondents is found to be significant as the Chi-square value is 84.026 with a p-value less than the level of significance (0.05). Thus, it can be concluded that age and health condition of respondents is associated.

It is evident from Table above that all the married respondents have sound health while majority of widow respondents have fair $(52.7 \%)$ and very poor $(35.2 \%)$ health conditions. The result indicates that the married respondents have sound health when compared with the widow respondents. Moreover, the association between marital status and health status of respondents is found significant since the Chi-square value is 148.307 with a p-value less than the level of significance (0.05). Hence, it can be inferred that there is an association between marital status and health status. Similarly, a significant association was found between very poor health status and Shudra followed by Kshatriya caste. By type of family a significant 32(18.4 per cent) elderly were belongs to joint family, who have poor health status.

It is evident that the self stated very poor health status is in very category the majority was from the Garhwal mountain region, females those were widows, those were above 81 years, Shudra by caste followed by Khatriya caste, residing in joint family, living in kuchha houses, civil pensioners, educated above high school \& above and average income group followed by high and low income group of the elderly households. However, with respect to the poor health status, Occupation, Education and Income of the household of elderly as the p-values associated with the $\mathrm{Ch}$-square statistics is found to be less than the level of significance (0.05).

\section{DISCUSSION}

Old age means reduced physical ability, declining mental ability, the gradual giving up of role playing in socio-economic activities, and a shift in economic status moving from economic independence to economic dependence upon other's for support. The expectancy of life in India is much less than 72 years. Psychologically too, most state population in Uttarakhand appear to consider themselves old earlier than the chronological age of 60 years and the mountain women regard themselves to be old even much earlier [8].

The present study also indicates that in the study villages $101(55.2$ per cent) elderly respondents were male and 82 (45.8 per cent) were female respondents. Out of them 92(50.2 per cent) elderly were married followed by 90 (49.2 per cent) widows. The self stated health status of females was found only $3.6 \%$ very good, $12.2 \%$ good, $47.6 \%$ fair and $36.6 \%$ very poor. Hence, a majority of the females have found very poor health status in the present study.

As per the 52nd round of National Sample Survey Organization, nearly half of the elderly are fully dependent on others, while another 20 percent are partially dependent for their economic needs [9]. About $85 \%$ of the aged had to depend on others for their day to day maintenance. The situation was even worse for elderly females [10]. 


\section{International Journal of Current Science Research and Review}

ISSN: 2581-8341

Volume 04 Issue 10 October 2021

DOI: 10.47191/ijcsrr/V4-i10-19, Impact Factor: 5.825

IJCSRR@ 2021

Www.ijcsrr.org

The present study also found that a majority 81 (44.3 per cent) were dependent on a mere income of rupees 2000 or less, while 36 (19.7 per cent) elderly people were in between the income bracket of rupees above 2000 and below 10,000, followed by 37 (20.2 per cent) in between above rupees 10,000 and below 20,000, 24 (13.1 per cent) in between above 20,000 and below 30,000 and only 5(2.7 per cent) elderly household belongs to an income of rupees 30,000 and above.

The analysis on self-rated health shows about 55 per cent of the elderly rating their health as poor or fair on a five point scale. Self-rated health also has a close connection with mental and physical health of the elderly.(11) Present study also found that a slightly less than 52.5 per cent elderly self stated health status as fair.

With respect to the healthcare access of the elderly people when in need, Sharma et al. in their study among elderly population in North India found that majority of the older persons preferred allopathic medicine ( 81.2 per cent) followed by Ayurvedic medicines (11.3 per cent). (12) Present study found a slight less 75.9 per cent elderly preferred the allopathic medicine followed by 10.6 per cent people has an access of Ayurvedic medicine by the elderly people in Uttarakhand mountain region.

\section{CONCLUSION}

The study revealed that in mountain region of Uttarakhand those elderly people were in very poor health status at the time of study survey, majority of those were from Garhwal region, females particularly widows, above the age of 81 years, Shudra by caste, residing in joint family, living in Kuchha houses.

Further, those were pensioners from civil department, were educated above high school and those were an average (between INR 2000/- to INR10, 000/-) were also has a self stated poor health stated.

The study further found that a majority of 75.9 per cent of elderly people has taken treatment in Allopathic system to cure their ailment. While a 10.4 per cent per cent elderly people has approached to Ayurvedic system of medicine followed by A Spiritual / Faith healing, Homeopathic \& others.

Hence, it was evidenced from this study that in built social determinants were like regional status, being a female, and further widowhood, Shudra by caste, being old-old (above 81 years of age), residing in joint family and Kuchha house were more responsible determinants responsible for the poor health of elderly people and majority of them approaches to allopathic system when sick in the region.

Elderly people are vulnerable segment of population. Therefore, there is an immense need to strengthen the healthcare provisions particularly those are from rural and far flung areas of mountain region, of scheduled caste, those are widows, very old, and have low living amenities.

\section{ACKNOWLEDGEMENT}

Hi this paper is an outcome of study entitled "Social Determinants of Health and Health Equity among the Elderly People in Mountain Region of Uttarakhand". The study of Social Determinants of Health \& Health Seeking Behaviour among Elderly People in Mountain Region of Uttarakhand by the author under an award of an ongoing Senior Fellowship (2019-20) by the Indian Council of Science Research (ICSSR), Ministry of Education, Government of India at SOSS, Uttarakhand Open University, Haldwani Uttarakhand.

\section{CONFLICT}

There is no any conflict for the study.

\section{REFERENCES}

1. WHO 1978. Declaration of Alma-Ata,Geneva, World Health Organization.

2. WHO 1986. Ottawa Charter for Health Promotion. Geneva, World Health Organization, Geneva.

3. Catford J 2005. The Bangkok Conference: steering countries to build national capacity for health promotion. Health Promotion International, 20:1-6.

4. CSDH (Commission on Social Determinants of Health), 2008.Closing the Gap in a Generation: Health Equity through Action on the Social Determinants of Health. World Health Organization, Geneva.

5. Sen A 1999. Development as Freedom. New York, NY, Alfred A. Knopf, Inc 


\section{International Journal of Current Science Research and Review}

ISSN: 2581-8341

Volume 04 Issue 10 October 2021

DOI: 10.47191/ijcsrr/V4-i10-19, Impact Factor: 5.825

IJCSRR@ 2021

www.ijesrr.org

6. Baum F 2002. The new public health, 2nd ed. Melbourne, Oxford University Press.

7. UNDP, 2005. Human Development Report ,2005 - International Cooperation at a crossroads: Aid, Trade and Security in an unequal World. New York, NY, United Nations Development Programme.

8. Bose, A.B and K.D. Gangrade, (ed.), 1988, Aging in India: Problems and Potentialities, Citizenship Development, Society, Abhinav Publications, New Delhi.

9. National Sample Survey Organization ,1998 Morbidity and Treatment of Ailments July, 1995- June, 1996 (NSS 52nd Round) Report No. 441, New Delhi, Government of India.

10. GOI .2011. Situation Analysis of the Elderly in India. Central Statistics Office Ministry of Statistics \& Programme Implementation, Government of India.

11. Bijalwan Rajeev P., Maithili B., Semwal, V. D., Social and Health Status of Elderly People in the Selected Areas of Hardwar District in Uttarakhand, International Journal of Biomedical and Healthcare Science. Volume 6, Number 2, 2016, pp. 211-218

12. Sharma D, Mazta SR, Parashar A. Morbidity Pattern and Health Seeking Behavior of Aged Population Residing in Shimla Hills of North India: A cross-sectional study. J Family Med Prim Care 2013;2: 188-93.

Cite this Article: Dr. Hari S. Bisht (2021). Social Determinants of Health and Health Equity among the Elderly People in Mountain Region of Uttarakhand. International Journal of Current Science Research and Review, 4(10), 1370-1377 